\title{
INTRAMEDULLARY THORACIC MENINGIOMA: A RARE CASE REPORT AND REVIEW OF THE LIT- ERATURE
}

\author{
Mihail B. Kalnev ${ }^{1,3}$, Elena G. Poryazova ${ }^{2}$, Georgy S. Apostolov ${ }^{3}$, Ivo I. \\ Kehayov $^{1,3}$, Borislav D. Kitov ${ }^{1,3}$, \\ 1) Department of Neurosurgery, Faculty of Medicine, Medical University \\ Plovdiv, Bulgaria \\ 2) Department of General and Clinical Pathology, Faculty of Medicine, Medi- \\ cal University Plovdiv, Bulgaria \\ 3) Clinic of Neurosurgery, University Hospital "St. George", Plovdiv, Bulgaria.
}

\begin{abstract}
Only a few cases of intramedullary meningiomas in the cervical and thoracic region have been reported in the literature. We present a rare case of intramedullary meningioma in the lower thoracic region.

A 68-year-old woman with complaints of back pain, gait disturbance, and paresthesias in both lower extremities for 4 months was admitted to our institution. Initially, she presented with weakness in her legs that gradually deteriorated over time. The patient had been operated on for breast cancer 2 years prior to the onset of current complaints. The neurological examination revealed spastic inferior paraparesis (McCormick grade IV), hypoesthesia below Th10 dermatome, bowel and bladder disturbances. Magnetic resonance imaging of the thoracic spine demonstrated intramedullary tumor that was hypointense on T1 and T2-weighted images but showed homogenous enhancement after gadolinium administration. After gross total resection, the histopathological examination confirmed the diagnosis of atypical intramedullary meningioma.

CONCLUSION: The intramedullary meningiomas are extremely rare, but they should not be excluded from the differential diagnosis, especially in cases of intramedullary tumors with homogenous enhancement on magnetic resonance imaging. The best treatment strategy is gross total removal of the tumor.
\end{abstract}

Keywords: Intramedullary meningioma; atypical meningioma, MRI, surgery thoracic spine,

\section{INTRODUCTION}

Spinal meningiomas can occur in each segment of the spine, but they are most common in the thoracic region. Intradural extramedullary meningiomas account for $25 \%$ to $50 \%$ of all intradural extramedullary tumors, and the incidence is $0,5-2 / 100000$ per year [1]. Intra-extradural spinal meningiomas represent $5 \%-6 \%$ of the cases [2]. Only a few cases of intramedullary meningiomas have been reported in the literature [3].

We present a rare case of intramedullary meningioma in the lower thoracic spine and put stress on its clinical presentation, imaging findings, surgical techniques, and pathological results.

\section{CASE REPORT}

A 68-year-old woman had been operated on for breast cancer 2 before her current admission. She presented with progressive complaints of back pain, impaired gait, and paresthesias in both lower extremities. Gradually, she became dependent and was not able to walk unassisted. The neurological examination revealed spastic inferior paraparesis (McCormick grade IV), conductive hypoesthesia below $\mathrm{Th}_{10}$ dermatome, positive Babinski sign bilaterally, bowel and bladder disturbances. The thoracic magnetic resonance imaging (MRI) demonstrated an intramedullary lesion, measuring $9.1 \mathrm{~mm}$ in the sagittal plane at the level of $\mathrm{T}_{12}$ vertebra that was hypointense on $\mathrm{T} 1$ and $\mathrm{T} 2$-weighted images (Fig. 1). After gadolinium administration, the mass showed homogeneous enhancement (Fig. 2).

Fig. 1. MRI without contrast enhancement. A/ T1 isointense lesion $\mathrm{B} / \mathrm{T} 2$ - round hypointense lesion with fusiform dilatation of the spinal cord.

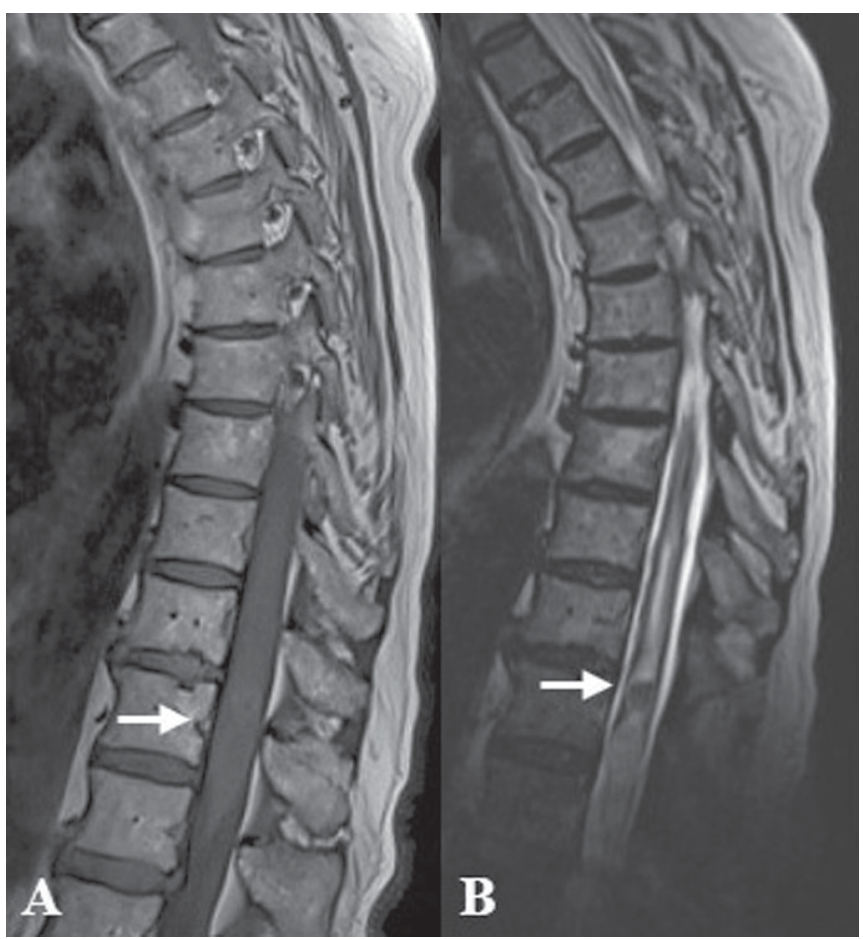


Fig. 2. MRI before and after gadolinium enhancement: A/ T1 MRI without enhancement - isointense lesion. B/ B/ T1 after enhancement - homogenous enhancement of the tumor mass.

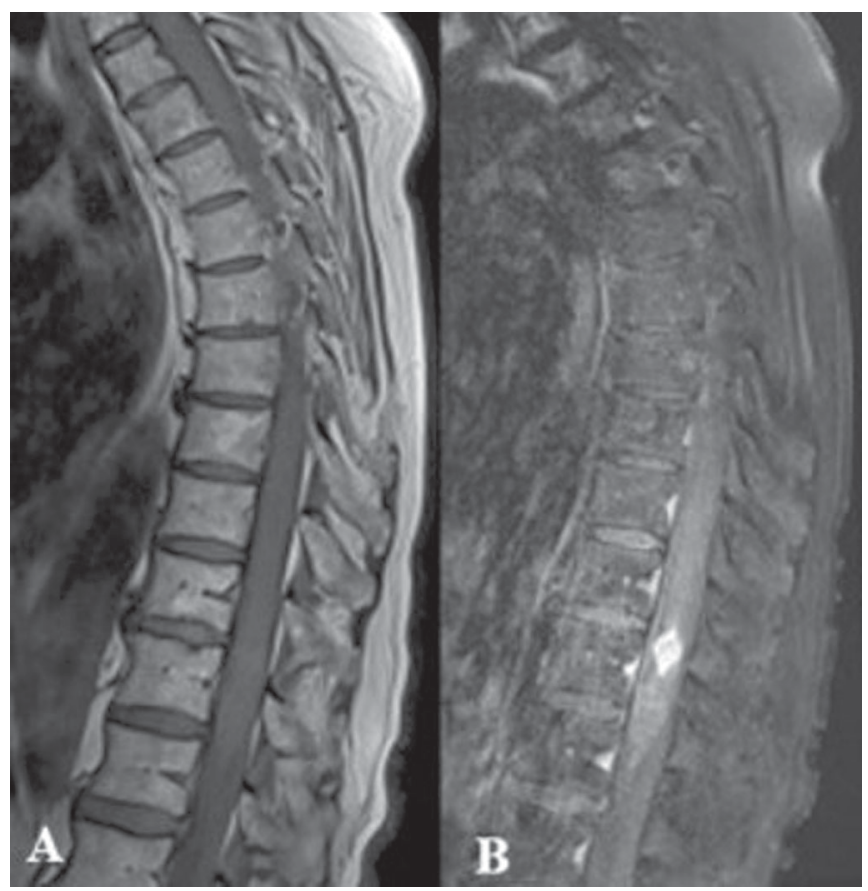

Taking into account the history of oncological disease, the lesion was initially interpreted as intramedullary metastasis. The patient underwent a $\mathrm{T}_{11}-\mathrm{T}_{12}$ laminectomy, midline durotomy and ultrasonic localization of the lesion. After posterior midline myelotomy, a pale grayish tumor was visualized that had rubbery consistency (Fig. 3 A). Using microsurgical technique, gross total resection of the tumor was achieved (Fig. 3 B).

Fig. 3. Intraoperative photos. A/ Posterior myelotomy B/ Post resection of the tumor.

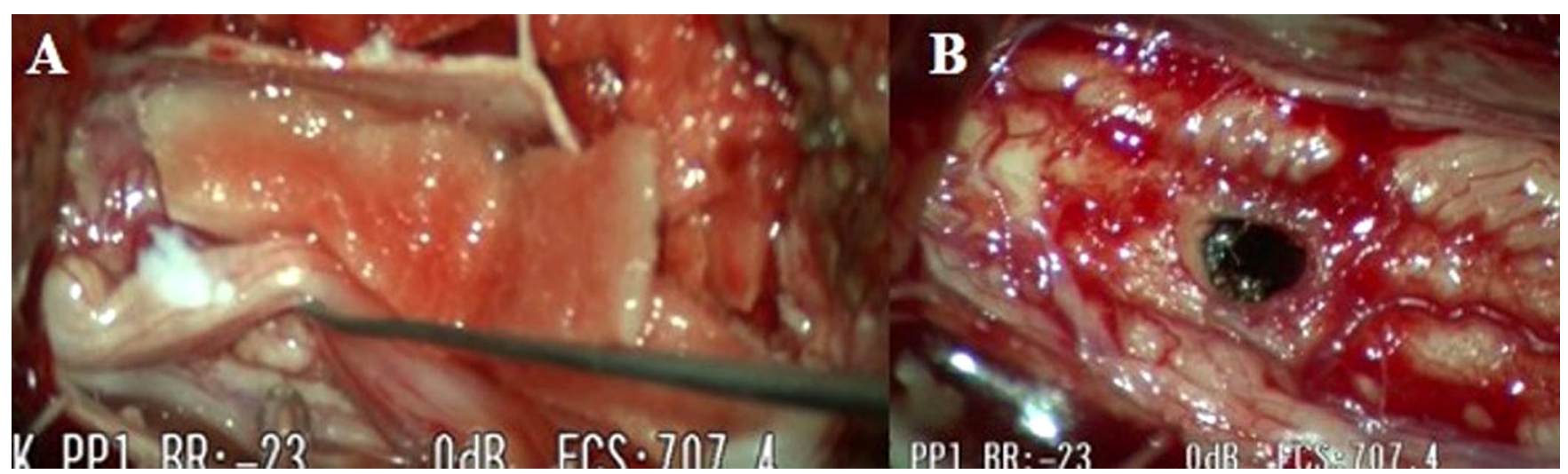

The histopathological examination confirmed a tumor with a presence of small, atypical, hyperchrome cells expressing high mitotic index, macronucleoli, and hypercellularity. The diagnosis of atypical meningioma (Grade II WHO) was confirmed (Fig. 4).

Fig. 4.

Atypical meningioma X-EX400 (WHO Grade II). Increased cellularity (white arrow); Small atypical cells with high N/C ratio (black-white arrow); Large and prominent nucleoli (white arrowhead).

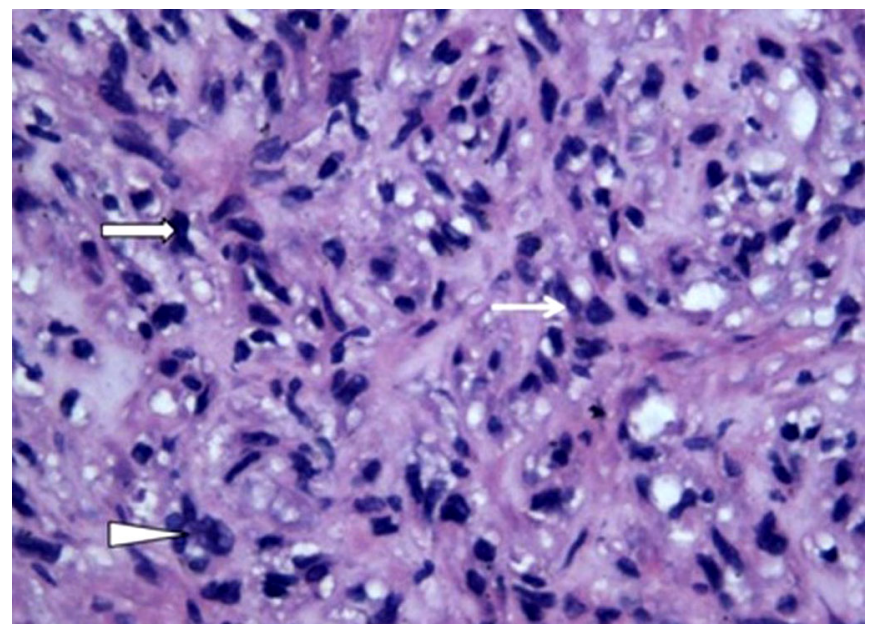


In the postoperative period, the patient demonstrated favorable recovery of the neurological deficit. At the second postoperative week, she was able to walk assisted. At the 8th postop month, she died due to progression of the systemic breast cancer disease.

\section{DISCUSSION}

Intradural extramedullary meningiomas account for $25 \%-46 \%$ of the spinal tumors [3]. The peak incidence of spinal meningiomas is between the 5 th and the 7 th decade, but they can occur at any age. Women are commonly affected (75-80\% of the cases), and the female: male ratio is $4: 1-8: 1$ [2].

Spinal meningiomas demonstrate homogenous enhancement after gadolinium administration and appear mildly hyperintense on T1- and T2-weighted MRI images [4]. Another typical characteristic is the so-called "dural tail sign" observed on post-contrast T1 MRI series but in the case of intradural extramedullary localization [3].

According to Klekamp, the intramedullary tumors represent about $5 \%$ of all spinal tumors, while intramedullary meningiomas are under $1 \%[5,6]$.

Because of their rarity, the imaging characteristics of intramedullary meningiomas are not well described. In most cases, they are iso- or hypointense on T1 sequences and mildly hyperintense on T2 sequences (with homogeneous enhancement?) [7]. This is also confirmed in our clinical case.

The pathogenetic mechanism of development is still unknown. According to Moriuchi et al., meningocytes are modified fibroblasts deriving from mesenchymal cells. Therefore, intramedullary meningiomas could develop in the mesenchymal cells lining the perivascular spaces of the neuraxis [8].

There are 16 case reports of intramedullary meningiomas in the literature (Table 1) [3, 7-21]. 9 of them were men, and 7 were women with an average age of 49 years ( 7 - 69). According to their localization, 8 of these intramedullary meningiomas were located in the cervical region (50\%), 1 in the cervicothoracic region $(6,2 \%)$, and seven cases in the thoracic region $(43,8 \%)$. As far as we know, our case is the first described in the lower thoracic region. This confirms that intramedullary meningiomas could affect the spinal cord at any level. In contrast to other meningiomas, the intramedullary meningiomas occur more often in the younger patient, male gender and are located predominantly in the cervical region.

Table 1. Intramedullary spinal cord meningiomas: a review of reported cases

\begin{tabular}{|l|l|l|l|}
\hline Autors & Sex/Age & Locallization & Pathohistological type \\
\hline Sakaki, et al. [9] & $\mathrm{M} / 12$ & Intramedullary & Meningioma \\
\hline Salvati et al. [10] & $\mathrm{F} / 67$ & $\mathrm{C}_{\mathbf{2}}-\mathrm{C}_{\mathbf{4}}$ & Fibroblastic \\
\hline Moriuchi et al. [8] & $\mathrm{F} / 54$ & $\mathrm{C}_{\mathbf{2}}-\mathrm{C}_{\mathbf{4}}$ & Transitional \\
\hline Jallo, et al. [11] & $\mathrm{F} / 8$ & $\mathrm{C}_{\mathbf{3}}-\mathrm{C}_{\mathbf{5}}$ & Clear cell \\
\hline Covert, et al. [12] & $\mathrm{F} / 69$ & $\mathrm{~T}_{\mathbf{2}}-\mathrm{T}_{\mathbf{3}}$ & Anaplastic \\
\hline Raza, et al. [13] & $\mathrm{F} / 65$ & $\mathrm{~T}_{\mathbf{2}}-\mathrm{T}_{\mathbf{6}}$ & Atypical \\
\hline Park, et al. [14] & $\mathrm{F} / 65$ & $\mathrm{~T}_{\mathbf{9}}-\mathrm{T}_{\mathbf{1 0}}$ & Clear cell \\
\hline Salehpour, et al. [15] & $\mathrm{M} / 21$ & $\mathrm{C}_{\mathbf{2}}$ & Syncytial type \\
\hline Sahni, et al. [7] & $\mathrm{M} / 42$ & $\mathrm{C}_{\mathbf{3}}-\mathrm{T}_{\mathbf{2}}$ & Atypical \\
\hline Yuan, et al. [16] & $\mathrm{M} / 33$ & $\mathrm{~T}_{\mathbf{1}}-\mathrm{T}_{\mathbf{3}}$ & Low grade \\
\hline Hafiz, et al. [17] & $\mathrm{F} / 7$ & $\mathrm{C}_{\mathbf{2}}-\mathrm{C}_{\mathbf{4}}$ & Atypical \\
\hline Pant, et al. [18] & $\mathrm{M} / 15$ & $\mathrm{~T}_{\mathbf{7}}-\mathrm{T}_{\mathbf{8}}$ & Transitional \\
\hline Perven, et al. [20] & $\mathrm{M} / 52$ & $\mathrm{C}_{\mathbf{5}}$ & Whorling-sclerosing \\
\hline Piazza, et al. [18] & $\mathrm{M} / 64$ & $\mathrm{~T}_{\mathbf{3}}-\mathrm{T}_{\mathbf{4}}$ & Low-grade \\
\hline de Oliveira Costa, et al.[21] & $\mathrm{M} / 67$ & $\mathrm{C}_{\mathbf{6}}-\mathrm{C}_{\mathbf{7}}$ & Angiomatous \\
\hline Cheng, et al. [3] & $\mathrm{M} / 46$ & $\mathrm{~T}_{\mathbf{6}}-\mathrm{T}_{\mathbf{7}}$ & Fibroblastic \\
\hline
\end{tabular}

Surgery should be the primary treatment. Total tumor resection is usually possible using a meticulous microsurgical technique. Interestingly, satisfactory results are reported after gross total or partial resections [3, 8, 10, 11, 18, 19].

The histological types of reported intramedullary meningiomas are presented in Table 1 . We can summarize that most of them are not benign, consistent with WHO Grade II, a fact also confirmed by our case. Therefore, cautious MRI follow-up is needed to detect early signs of recurrence. In such cases, adjuvant radiotherapy should also be considered.

\section{CONCLUSION}

The diagnosis of intramedullary meningiomas should not be excluded in cases with long-lasting complaints caused by lesions located within the spinal cord that demonstrate homogeneous enhancement detected on magnetic resonance imaging. Microsurgical gross total resection should be the mainstay treatment of choice of such tumors. Close MRI follow-up is necessary to exclude recurrence of atypical intramedullary meningioma. 
REFERENCES:

1. Setzer M, Vatter H, Marquardt G, Seifert V, Vrionis FD. Management of spinal meningiomas: surgical results and a review of the literature. Neurosurg Focus. 2007; 23(4):E14. [PubMed]

2. Pereira CU, Dias LAA, Dezena RA. Spinal Meningiomas: report of 14 cases and literature review. J Bras Neurocirurg. 2015 Mar;26(2):11015.

3.Cheng C, Wang J, Zhao S, Tao B, Bai S, Shang A. Intramedullary Thoracic Meningioma: A Rare Case Report and Review of the Literature. World Neurosurg. 2019 Sep;129:176-180. [PubMed]

4. Pinter NK, Pfiffner YJ, Mechtler LL. Neuroimaging of spine tumors. Handb Clin Neurol. 2016; 136:689706. [PubMed]

5. Koeller KK, Rosenblum RS, Morrison AL. Neoplasms of the spinal cord and filum terminale: radiologicpathologic correlation. Radiographics. 2000 Nov-Dec;20(6):172149. [PubMed]

6. Klekamp J. Treatment of intramedullary tumors: analysis of surgical morbidity and long-term results. $J$ Neurosurg Spine. 2013 Jul;19(1):1226. [PubMed]

7. Sahni D, Harrop JS, Kalfas IH, Vaccaro AR, Weingarten D. Exophytic intramedullary meningioma of the cervical spinal cord. J Clin Neurosci. 2008 Oct;15(10):1176-79. [PubMed]

8. Moriuchi S, Nakagawa $\mathrm{H}$, Yamada M, Yamada M, Kadota T. Intramedullary spinal cord meningioma-a case report. Neurol Med Chir
(Tokyo). 1996 Dec;36(12):888-92. [PubMed]

9. Sakaki S, Ohsugi T, Chaki T, Shiraishi M, Matsuoka K, Go S. Total removal of an intramedullary meningioma of the medulla oblongata-case report. Neurol Med Chir (Tokyo). 1987 Jul;27(7):658-62. [PubMed]

10. Salvati M, Artico M, Lunardi P, Gadliardi FM. Intramedullary meningioma: case report and review of the literature. Surg Neurol. 1992 Jan; 37(1):42-5. [PubMed]

11. Jallo GI, Kothbauer KF, Silvera VM, Epstein FJ. Intraspinal clear cell meningioma: diagnosis and management: report of two cases. Neurosurgery. 2001 Jan;48(1):218-21. [PubMed]

12. Covert S, Gandhi D, Goyal M, Woulfe J, Belanger E, Miller W, et al. Magnetic resonance imaging of intramedullary meningioma of the spinal cord: case report and review of the literature. Can Assoc Radiol J. 2003 Jun;54(3):177-80. [PubMed]

13. Raza SM, Anderson WS, Eberhart CG, Wolinsky JP, Gokaslan ZL. The application of surgical cordectomy in the management of an intramedullary-extramedullary atypical meningioma: case report and literature review. J Spinal Disord Tech. 2005 Oct;18(5):449-54. [PubMed]

14. Park SH, Hwang SK, Park YM. Intramedullary clear cell meningioma. Acta Neurochir (Wien). 2006 Apr; 148(4):463-66. [PubMed]

15. Salehpour F, Zeinali A, Vahedi P, Halimi M. A rare case of intramedullary cervical spinal cord meningi- oma and review of the literature. Spinal Cord. 2008 Sep;46(9):648-50. [PubMed]

16. Yuan D, Liu D, Yuan X-R, Xi J, Ding H-P. Intramedullary thoracic spinal cord meningioma: a rare case report and review of the literature. $J$ Neurol Surg A Cent Eur Neurosurg. 2013 Dec;74(Suppl 1):e136-9. [PubMed]

17. Hafiz MG, Rahman MR, Yeamin MB. Intradural intramedullary spinal cord meningioma in a seven years old female child. Mymensingh Med J. 2013 Jan;22(1):180-5. [PubMed]

18. Pant I, Chaturvedi S, Gautam VK, Kumari R. Intramedullary meningioma of spinal cord: case report of a rare tumor highlighting the differential diagnosis of spinal intramedullary neoplasms. Indian J Pathol Microbiol. 2014 Apr-Jun;57(2):30810. [PubMed]

19. Perven G, Entezami P, Gaudin D. A rare case of intramedullary "whorling-sclerosing" variant meningioma. Springerplus. 2015 Jul 4;4: 318. [PubMed]

20. Piazza MA, Ramayya AG, Geiger GA, Alonso-Basanta M, Nasralah ML, Welch WC, et al. Intramedullary recurrence of a thoracic meningioma - presentation of an unusual case and review of the literature. World Neurosurg. 2016 Aug;92:588.e1-588.e21 [PubMed]

21. Costa FAO, Fabião OM, Chaves JPG, Fabião JD, Jorge VM. et al. Intramedullary Cervical Spinal Cord Meningioma: A Rare Case Report. Arq Bras Neurocir. 2016 Jan;35(1):82-84. [Crossref]

Please cite this article as: Kalnev MB, Poryazova EG, Apostolov GS, Kehayov II, Kitov BD. Intramedullary thoracic meningioma: a rare case report and review of the literature. J of IMAB. 2021 Oct-Dec;27(4):3995-3998.

DOI: https://doi.org/10.5272/jimab.2021274.3995

Received: 07/01/2021; Published online: 01/10/2021

\author{
Address for correspondence: \\ Mihail B. Kalnev \\ Department of Neurosurgery, Faculty of Medicine, Medical University Plovdiv, \\ Clinic of Neurosurgery, University Hospital "St. George", Plovdiv, \\ 66, Peshtersko chose Str., 4000 Plovdiv, Bulgaria \\ E-mail: dr.kalnev@gmail.com
}

